\author{
E-ISSN: 2469-6501 \\ VOL: 7, ISSUE: 10 \\ October/202 1 \\ DOI: http://dx.doi.org/10.33642/ijbass.v7n10p4

\title{
Identifying Potentially Successful Start-up Social Enterprises
}

\author{
Asceline Groot \\ Partner at HetkanWEL, The Netherlands \\ https://www.linkedin.com/in/ascelinegroot/ \\ Email: a.groot@ hetkanwel.nl \\ The Netherlands \\ Ben Dankbaar * \\ Institute of Management Research \\ Radboud University Nijmegen, The Netherlands \\ https://www.linkedin.com/in/bendankbaar \\ Email: ben.dankbaar@ru.nl \\ The Netherlands
}

\section{ABSTRACT}

This paper investigates the characteristics of 347 project ideas that had the potential to develop and, in many cases, did develop into social enterprises. Insight into these characteristics may help impact investors identify potentially successful social enterprises at an early stage. At this stage, the terms of a business case are usually not figured out yet, but the plans have the potential to create social as well as financial value. The project ideas were posted on a Dutch online platform. The initiators described their social goals, the need for resources, and their plans for the execution in their own words. We compared the characteristics of the ideas that survived with the ones that didn't. It appears that potential social entrepreneurs have a higher chance to survive if they are at first less focused on the financial issues of their business and more on the impact they want to achieve.

Keywords: Social entrepreneurship; start-up social enterprise; impact investment; social change; resource mobilisation.

\section{Introduction}

This paper is concerned with the early stages of the development of social enterprises. Analyzing a large database of individual ideas and proposals for social change, we investigate the characteristics of ideas that can develop and have developed into social enterprises. Insight into these characteristics may help to identify potentially successful social enterprises at an early stage. This will be of interest to impact investors interested in supporting social enterprises. The challenge for the impact investor is to identify ideas with potential at a stage where the proponents of the ideas are often not yet thinking in terms of a business case because they are still more concerned with the social issue to be addressed.

We are looking for early signals of successful social entrepreneurship in the way people present their ideas. An impact investor would also be interested in the personality and experience of the would-be entrepreneur, but in this paper, we are interested in the characteristics of the proposals and not of the persons who made them. Our database was not designed to help impact investors but to support the exchange of ideas between people who want 'to have a positive impact on the world'. For our analysis, this has the positive effect that the ideas and proposals in our database were not written down specifically to make a good impression on investors.

In the following section, we briefly discuss the concept of social entrepreneurship and the definition we use in our research. Section 3 describes the changing financial environment for social enterprises, the rise of impact investment, and the interest in early signals of social entrepreneurship. Section 4 describes the database we have used. Section 5 describes the research procedures we have followed. In section 6 we analyze some general trends in the data and describe the main characteristics of the complete data set. In sections 7 and 8 , we describe the characteristics of potential social entrepreneurial project ideas. Taking survival as an indicator of success, we compare successful and unsuccessful projects, looking for early signals of a viable business case. In section 9 we draw some conclusions.

\section{Social entrepreneurship}

The definition of social entrepreneurship has been a subject of considerable debate over the years and there is still no widely prevailing definition (Mair and Marti 2006; Dacin et al. 2010; Macke et al. 2018). People have different ideas of what is social and what is not (Nicholls \& Cho 2006; Lumpkin et al. 2013; Santos 2012) and the meaning differs between countries and regions. According to Light (2008), the rise of social entrepreneurship is a reaction to governments spending less money on social provisions, environmental issues, and international aid programs in the nineties and early $21 \mathrm{st}$ century. For example, the homeless and the elderly in the West were affected by a reduction of welfare state provisions, while subsistence farmers in developing countries were affected by 


\author{
E-ISSN: 2469-6501 \\ VOL: 7, ISSUE: 10 \\ October/202 1 \\ DOI: http://dx.doi.org/10.33642/ijbass.v7n10p4

reductions in development aid budgets. Several organizations saw these diverse problems as opportunities. Dees and Battle Anderson (2006) investigated these organizations and distinguished two types of social entrepreneurial activity: (1) NGOs that use business methods and (2) entrepreneurs with a social mission. Many NGOs have developed some kind of business on the side. Most of them still depend on donations and subsidies from the government, companies, and private donors, but they also use business methods to generate their income to reduce this dependency, for example by selling products in a webshop. The profit is then invested in their social mission. An old and well-known example of this is Unicef selling Christmas Cards. Entrepreneurs with a social mission approach one or more social problems in an entrepreneurial way. They use business methods for social change and their companies are mission-driven.

The distinction between NGOs and enterprises with a social mission is central in the literature on social entrepreneurship (Hoogendoorn et al. 2010; Dees 1998; Bornstein 2007; Leadbeater 1997) and has led to a lively discussion on profit-making. Some authors have defined social enterprises as not-for-profit organizations that use business methods (Dees et al. 2002; Weerawardena and Mort 2006). Others define them as enterprises with a social mission that make a profit (Acs et al. 2011; Wilson \& Post 2013; Scott Marshall 2011). Some authors argue that the distinction between forprofit and not-for-profit is not very clear in practice (Kramer 2005; Dees and Battle Anderson 2006; Santos 2012). Most people would probably agree that a not-for-profit organization depending purely on subsidies and charity should not be called an enterprise, but what if the organization is covering most of its costs with commercial activities? And what if a not-forprofit organization makes a profit and reinvests it back into the organization and/or its social mission?

We subscribe to the view that social entrepreneurs require a viable business model with a double bottom line' (Acs et al. 2013; Lumpkin et al. 2013; Groot and Dankbaar 2014). We define social entrepreneurship as entrepreneurship to achieve social change through a viable business case. The social enterprise develops a product or service that can be sold to paying customers. The focus areas of social enterprises are diverse. Some focus on people in need, others on environmental issues; some hope to influence the behavior of consumers or companies; others aim to change the rules and institutions of society. For all social enterprises, regardless of their focus, making money is the only way to survive in the long run (Bugg-Levine et al. 2012; Weerawardena \& Mort 2006).

\section{The changing financial environment of social entrepreneurship}

Social entrepreneurship is a fairly new concept and the attention it generates is increasing every year. Research on the topic is expanding and the number of published scientific articles is growing, just like the attention the concept generates in the media, business, government, and politics (Macke et al.; 2018). The increasing attention makes people confident that creating social and financial value can go hand in hand. The fact that promoting social change can also be a promising business opportunity was not necessarily something people 10 or 15 years ago realized (Moore et sl. 2012).

Until recently, if people wanted to change society, they mainly thought in terms of political action, awareness campaigns, volunteer work, donations, and subsidies. They seldom thought in terms of business ideas. However, the circumstances have changed. Because of the economic recession in 2008, funding projects for social change became more difficult. This forced people to come up with new ways to finance their activities. Some internationally publicized examples, like the Indian community development Grameen Bank, had already proven that creating social and financial value could go hand in hand (Bornstein 1996). Thus, diminishing subsidies and inspiring examples combined create a climate in which the interest for and support of social entrepreneurship increased rapidly (Financial Times 2018).

Along with the growing number of social enterprises, the number of social or impact investors grew too (Arena et al. 2018; Ormiston et al. 2015; Roundy et al. 2017; CNN; Cohen and Sahlman 2013; Agrawal \& Hockerts 2021). These investors search for business opportunities that offer them a social and financial return on investment (Bugg-Levine et al. 2012). They invest in companies, projects, and social enterprises with a track record, in scale-ups, in start-ups, or a combination of all. As a result, more financial means have become available for social enterprises. This is good news for social entrepreneurs. It may even result in some competition between different impact investors who are all looking for investment opportunities with the greatest impact. For an investor, it would be helpful to identify potential social enterprises by early signals of success. If the investor identifies potentially successful social entrepreneurs in an early stage and then supports them with different resources like knowledge, training, or network during the idea development phase, a relationship of trust can develop between the investor and the entrepreneur (Geobey et al. 2012). When the social enterprise is ready to take the next step, the investor will be ready to invest financially with confidence. This raises the question of what these early signals might be. The database of 'Voor de Wereld van Morgen' provides some insights in this regard.

\section{A database of ideas for social change}

Looking for early signals of success, we investigated a database of project ideas that were launched on the platform 'For Tomorrow's World' (Voor de Wereld van Morgen, www.voordewereldvanmorgen.nl, VDWVM), which was initiated by Dutch ASN Bank in 2007. It contains 1487 project ideas for social change that were entered into the database between 2008 and 2014. ASN Bank has focused on socially responsible banking from its foundation by the Dutch Federation of Unions in 


\author{
E-ISSN: 2469-6501 \\ VOL: 7, ISSUE: 10 \\ October/202 1 \\ DOI: http://dx.doi.org/10.33642/ijbass.v7n10p4 \\ (C) (†) \\ https://creativecommons.org/licenses/by/4.0/
}

1960. The bank's mission is to improve the sustainability of society by investing in organizations and projects that stimulate sustainable progress. ASN Bank started VDWVM as an online platform for smart ideas for a better world. The reason to start the platform was that the number of people asking the bank for financial support for sustainable projects was growing every year, but the sponsor budget was not sufficient for the aid asked - and not everyone who asked for money needed it. Most of the time non-financial resources like specific expertise, training, or coaching were a better investment to get the projects started.

With this in mind, the bank came up with the idea of an online community where people would be able to mobilize resources to carry out their ideas for social change. The goal was that the community would grow organically and more and more projects would be started and completed that would contribute to the bank's mission. The bank would organize, monitor, and mobilize the 'marketplace' where supply (people with resources) and demand (people who needed resources) would come together. The bank would share its network and media channels, organize training, challenges, and competitions to increase the number of people involved in the community. Ideas for social change could be posted online and the initiators could describe their ideas and inspire people to support or follow them. People who didn't have their project, but were willing to help one, could contact the project initiator. Once a year the bank directly donated money to one or more projects through a competition, the ASN Bank World Award (the ASN Bank Wereldprijs).

The small but ambitious initiative that started in 2007 is today a platform that has hosted over 3000 project ideas, reaches thousands of followers on social media, is involved in multiple projects in the media, and supports early start-up social enterprises. Our research focuses on the ideas posted at VDWVM during the period 2008- 2014. In 2008 the website was launched and until December 2014 the conditions and procedures for entering ideas were the same. In January 2015 the website received a makeover and the procedures and themes were changed. To be able to compare the years we chose to analyze the period before the introduction of the new website.

\subsection{Posting an idea on the platform, how did it work}

Start-up companies, not-for-profit organizations, or private persons (from now on all called initiators) could create an account on the website and post their project idea. Table 1 shows the format for the information that the initiators posted online in the period 2008-2014.

\begin{tabular}{|c|c|}
\hline $\begin{array}{l}\text { Field } \\
\text { Title }\end{array}$ & $\begin{array}{l}\text { Description of content } \\
\text { Short and snappy title }\end{array}$ \\
\hline Abstract & Abstract of the idea \\
\hline Motive & Why does the initiator want to do this \\
\hline Social aim & What does the initiator want to change \\
\hline Execution & How will the initiator reach his aim \\
\hline $\begin{array}{l}\text { Extra } \\
\text { Facebook }\end{array}$ & $\begin{array}{l}\text { Whatever the initiator wants to tell that is relevant for the readers } \\
\text { Connection with Facebook }\end{array}$ \\
\hline Twitter & Connection with Twitter \\
\hline Website & URL of website \\
\hline Theme & The community has five themes, one must be chosen \\
\hline
\end{tabular}

Table 1: description of a project

There were no restrictions on the kind of ideas people realize the idea should not already exist for more than 3 years could post, but a few conditions had to be met: (1) the and it should not conflict with the mission of the bank. The initiator(s) should be willing to execute the ideas themselves; editorial office of VDWVM checked all incoming project (2) the project ideas had to be related to the purpose of the ideas and decided if they could go online or not. The community; (3) the project-idea or the organization set up to assessment criteria are provided in Table 2. 


\author{
E-ISSN: 2469-6501 \\ VOL: 7, ISSUE: 10 \\ October/2021 \\ DOI: http://dx.doi.org/10.33642/ijbass.v7n10p4 \\ (c) $\underset{\mathrm{EY}}{\mathrm{i}}$ \\ https://creativecommons.org/licenses/by/4.0/
}

\begin{tabular}{|c|c|}
\hline Criteria & Description \\
\hline Creative/Innovative & $\begin{array}{l}\text { Do the ideas give innovative solutions for societal problems, or creative } \\
\text { alternatives for existing solutions? }\end{array}$ \\
\hline Impact & $\begin{array}{l}\text { Can the project have a positive impact on society? Does it influence } \\
\text { institutions or consumer behaviour? }\end{array}$ \\
\hline Achievable & $\begin{array}{l}\text { The idea can be big and difficult to realise, but with effort, money, } \\
\text { knowledge and support from a big group of people, is it possible? }\end{array}$ \\
\hline Theme & $\begin{array}{l}\text { The projects must fit one of the five themes of the community (sustainable } \\
\text { energy, nature and environment; fair trade, fair fashion, fair food; } \\
\text { children's rights and education; safety and social cohesion; all others), and } \\
\text { if they belong to the category 'all others' they must be very innovative }\end{array}$ \\
\hline Sustainable & All projects must fit the criteria for sustainability of ASN Bank. \\
\hline Constraints & $\begin{array}{l}\text { Initiators can be private persons or small enterprises or foundations in the } \\
\text { early start-up phase. Existing organisations that are active longer than } \\
\text { three years are excluded. }\end{array}$ \\
\hline
\end{tabular}

Table 2: assessment criteria of projects

By posting a project idea on the website, the initiators got access to knowledge, network, training facilities, (social) media channels, and sometimes funding. They were able to reach a big audience to mobilize supporters for their idea. The aim of the bank in creating this community was to help ideas to grow into successful projects, foundations, or social enterprises. At the beginning of the period we are analyzing, social entrepreneurship was not a well-known approach for social change in the Netherlands. The people posting their project ideas were often not aware of the concept of social entrepreneurship nor of the existence of impact investors. They were mainly looking for support from the people that joined the community. In 2012, the organization Social Enterprise NL was founded and the concept of social entrepreneurship was slowly gaining more awareness, but this is not yet visible in our database as we shall see below.

\section{Research approach}

We have analyzed the database in four steps. First, in a descriptive analysis, we scored all 1487 project ideas on five dimensions, which made it possible to come to a first rough categorization of the ideas and look for overall trends in the database. We also established which of these ideas were still alive and active in Autumn 2015 and again in Spring 2021. We consider projects as (potentially) successful if they survive over the years. In 2015, the oldest projects in the database were 6 years old; in 2021, the surviving projects were 6 to 12 years old. In a second step, we identified 347 project ideas that were taking an entrepreneurial point of view and mentioned or described a potential business model. In a third step, we looked for differences between the entrepreneurial ideas that had survived and the ones that didn't. We first looked at the four dimensions mentioned before and then we also investigated the descriptions of the ideas to see if there were differences between the survivors and the ones that were discontinued in the way they had described themselves. For the latter analysis, we used software counting the words in the project descriptions to see if the initiators used different terms to describe their ideas, or if they had a different understanding of the product or service they were aiming to sell. In a fourth and final step, we established which projects were still alive in Spring 2021 and repeated the third step for these projects.

\subsection{The first step-The complete database}

The descriptions of 1487 ideas that had been posted on VDWVM by the initiators according to the required format (Table 1) were exported from the website to an excel file. Based on the descriptions from the website, values could be determined for the following variables: potential organizational form, geographical focus, development of a product or service, theme, and use of social media (cf. Table 3). After this analysis of the VDWVM website, the analysis was extended with online research of the social media activity and the (if available) websites of the project ideas to determine if they were still active in 2015 or not. 


\author{
E-ISSN: 2469-6501 \\ VOL: 7, ISSUE: 10 \\ October/2021 \\ DOI: http://dx.doi.org/10.33642/ijbass.v7n10p4 \\ (c) $\underset{B Y}{(7)}$ \\ https://creativecommons.org/licenses/by/4.0/
}

\begin{tabular}{|c|c|}
\hline Dimension & Research procedure \\
\hline $\begin{array}{l}\text { 1. Theme }(5 \\
\text { categories) }\end{array}$ & $\begin{array}{l}\text { The initiator could choose one of five themes: } 1 \text {. Sustainable energy, nature and environment; } 2 \text {. } \\
\text { Fair trade, fair fashion, fair food; } 3 \text {. Children's rights and education; } 4 \text {. Safety and social cohesion; } \\
\text { 5. Other. }\end{array}$ \\
\hline $\begin{array}{l}\text { 2. Active on social } \\
\text { media (yes/no) }\end{array}$ & $\begin{array}{l}\text { A project-idea was considered active on social media if the initiator had an account on Twitter or } \\
\text { Facebook, and used it as a communication channel for the project-idea. }\end{array}$ \\
\hline $\begin{array}{l}\text { 3. Geographical focus } \\
\text { ( } 3 \text { categories) }\end{array}$ & $\begin{array}{l}\text { The initiator described where the geographical focus of the project was. In the Netherlands, } \\
\text { abroad, or both. }\end{array}$ \\
\hline $\begin{array}{l}\text { 4. Product or service } \\
\text { ( } 3 \text { categories) }\end{array}$ & $\begin{array}{l}\text { Were the initiators developing a product or service, or both? If the researchers were not able to } \\
\text { determine this, the project-idea was categorised as other. }\end{array}$ \\
\hline $\begin{array}{l}\text { 5. Potential } \\
\text { organizational form ( } 8 \\
\text { categories) }\end{array}$ & $\begin{array}{l}\text { The researchers determined the potential organisational form, based on the description of the } \\
\text { project-idea. In total } 8 \text { types in } 2 \text { categories were derived. } \\
\text { - Short-term project-ideas for a specific time period with a foreseen beginning and an ending: } \\
\text { 1/ project: if the initiator wanted to start an activity with a start and a finish and a specific goal. } \\
\text { 2/ event: if it aimed for people to come together with a specific theme } \\
\text { 3/ campaign: if the initiators wanted to make people aware of a certain topic. } \\
\text { - Long-term project-ideas: } \\
\text { 4/ social enterprise: when the project-idea fitted our definition of a social enterprise and } \\
\text { focused on improving the sustainability of people or planet with a potentially viable business } \\
\text { model. } \\
\text { 5/ foundation (not for profit): focused on helping people or planet with money obtained from } \\
\text { donations } \\
\text { 6/ network: if self-employed people were working together for the purpose of a social goal. } \\
\text { 7/ cooperative society: if different people, organizations and/or stakeholders could all take a } \\
\text { share in the project. } \\
\text { 8/ idea/technical invention, if no organizational form could be derived; the idea was just a } \\
\text { thought that needed to be further developed. }\end{array}$ \\
\hline 6. Active (yes/no) & $\begin{array}{l}\text { Between August and December } 2015 \text {, for every project-idea it was established if the initiators } \\
\text { were still active or not. If a project was active during the last six months on VDWVM, the project } \\
\text { website or social media, it was considered as active. If not, the project was considered inactive. }\end{array}$ \\
\hline
\end{tabular}

Table 3: Research procedure

\subsection{The second Step-Identifying potential social enterprises}

To determine if an idea could be a potential social enterprise, we focused first on the time perspective taken in the description of the project idea. We then divided the long-term project ideas into (1) project ideas that purely focused on helping people or the planet with money they would obtain from donations; and (2) other project ideas with a long-time horizon. From the latter category, ideas were earmarked as social entrepreneurial ideas if they met the following four criteria, (see also Figure 1).

1. A long-term commitment;

2. Focus on improving the wellbeing of people or planet, or both;

3. An idea for a product or service that could be sold to customers;

4. A focus on institutional change or change in the behavior of consumers or companies by showing that sustainable products or services can be a viable alternative.
In total, we found 347 ideas that fitted these criteria. Of these 347 project ideas, $229(66 \%)$ were still active in 2015 , of which 129 survived in 2021.

\subsection{The third Step-Analyzing the potential social enterprises}

We separated the active and inactive project ideas and looked for differences in the theme chosen, the use of social media, focus on a product or service, geographical focus, and project descriptions. In the analysis of the project descriptions, we made use of the word-count software program Nvivo (Bazeley \& Richards 2000). We searched for 'hidden' business terms related to the mobilization of money, consumers, marketing, sales, and other support. All social entrepreneurial project ideas were uploaded in Nvivo and the program produced a word count of the 1000 most used words with a length of at least five letters. In our analysis, we included only the words that came up more than ten times. We looked for differences in the project descriptions of the projects that were active and inactive in 2015 and repeated the analysis for the http://dx.doi.org/10.33642/ijbass.v7nnop4 


\author{
E-ISSN: 2469-6501 \\ VOL: 7, ISSUE: 10 \\ October/2021 \\ DOI: http://dx.doi.org/10.33642/ijbass.v7n10p4 \\ (c) (i) \\ https://creativecommons.org/licenses/by/4.0/
}

129 survivors in 2021, again comparing their project descriptions with the ones no longer active.

\section{Results for the complete database VDWVM 2008-2014}

This section describes the characteristics of all 1487 project ideas that were introduced on VDWVM from 2008 to 2014. We will not discuss the dimension 'use of social media, because it had the value 'yes' in practically all cases.

\subsection{Choice of theme}

The initiators had five themes to choose from. The initiator chose the theme that fitted the project idea best (Table
4). This made it easier for supporters visiting the website to find a project that interested them. Figure 1 shows that every year 50 percent or more of the projects chose the theme 'sustainable energy, environment, and nature. This theme was followed by the theme 'fair trade, fair fashion and fair food', but the percentage of projects in this category was only 10-20 percent. The other categories are small compared to the first two. Only in 2014 did we see a slightly different distribution. 'Safety and social cohesion' was considerably larger than in earlier years.

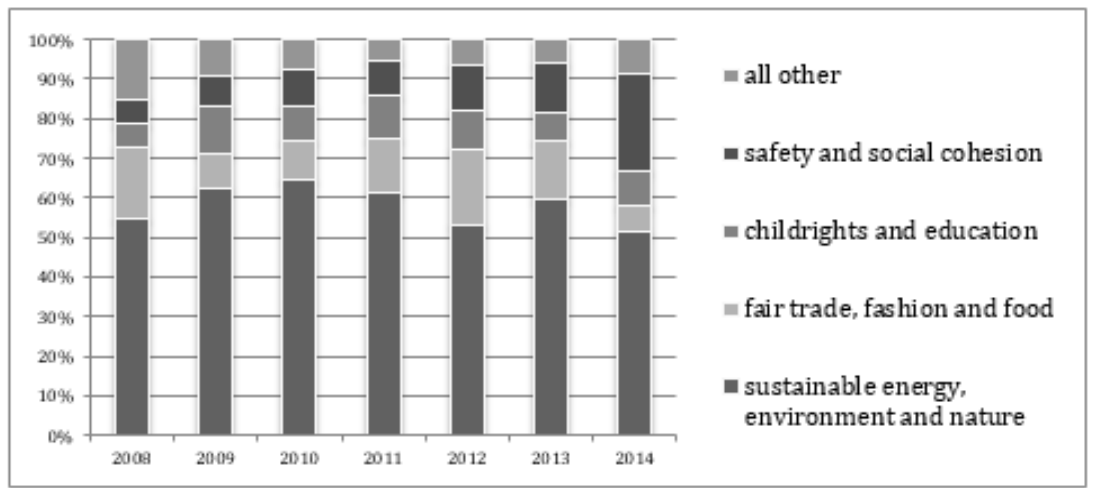

Figure 1: percentage division by theme in the period 2008-2014

\subsection{Geographical focus}

In some projects, the initiators focus on the social value they want to create in the Netherlands. Other initiators focus on social issues abroad, mainly in developing countries. And some focus on projects in the Netherlands with a link to other countries. For example, a washing powder is produced in Nepal, but packaging and distribution are done in social workplaces in the Netherlands. The social value is created in Nepal as well as in the Netherlands. In the complete database, 999 project-ideas $(68 \%)$ were focusing on social value creation in the Netherlands, 287 (19\%) focused on foreign countries, and $194(13 \%)$ on both (7 could not be determined). The percentage of projects that focus on other countries is fairly stable over the years. The year 2014 is an exception with almost $80 \%$ of the projects focusing on the Netherlands.

\subsection{Potential organizational forms}

When filing their project ideas, most initiators were in the early stages of the development of their idea or organization. Some of the initiators had a clear idea of the organizational form they would choose, others did not mention this directly, but it could be derived from their own words. The project description gave insight into the organizational forms the projects could take. Based on the description of the project ideas we classified all projects into eight potential organizational forms (cf. Table 3). Figure 2 shows these categories and the number of project ideas that fitted each category.

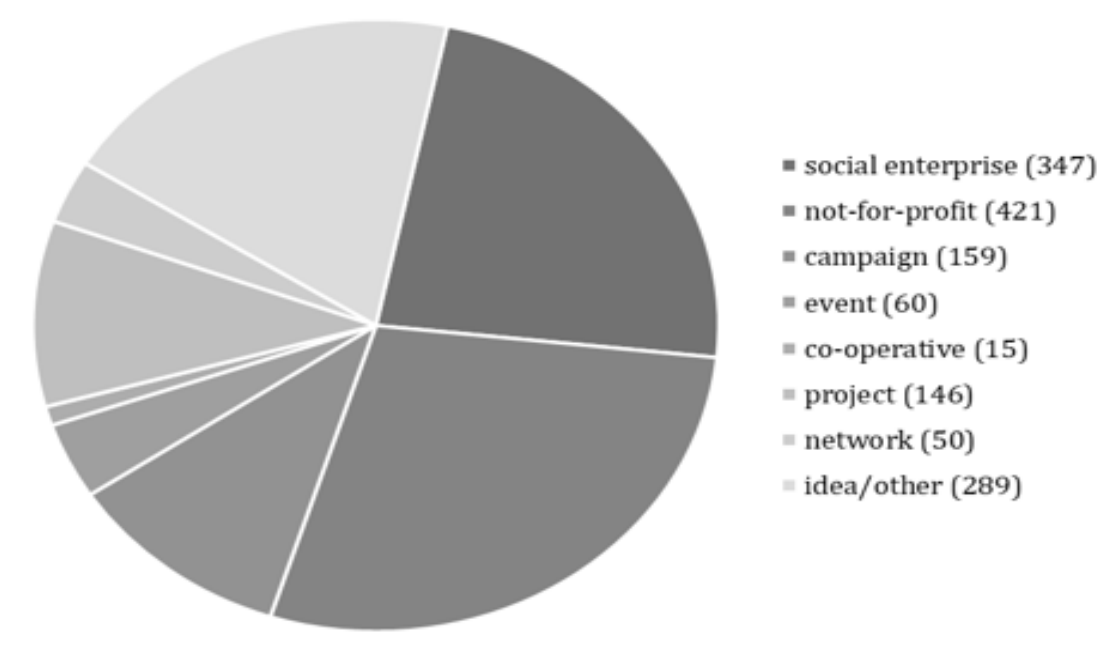

Figure 2: Division of project-ideas in potential organizational forms 


\author{
E-ISSN: 2469-6501 \\ VOL: 7, ISSUE: 10 \\ October/202 1 \\ DOI: http://dx.doi.org/10.33642/ijbass.v7n10p4 \\ (c) (†) \\ https://creativecommons.org/licenses/by/4.0/
}

\section{Results for the potential social enterprises}

This section takes a closer look at the 347 potential social entrepreneurial project ideas and discusses their general characteristics. In the next section, we look for other signals of social entrepreneurial behavior, based on the project descriptions.

\subsection{Survival rates}

Table 4 shows the total number of ideas for the years in which they were initiated, the number of social entrepreneurial (SE) ideas, and the ideas surviving in 2015 and (for the SE ideas) in 2021. The number of still-active projects initiated in any year is declining over the years. For instance, of the 276 ideas initiated in 2009, only $21 \%$ survived in 2015 . 45 of these ideas had the potential to become a social enterprise, of which 11 (24\%) survived six years later (2015). Six more years later (2021), 10 of them were still alive. Of the 76 social entrepreneurial ideas launched in 2014, 35\% were still alive six years later. This suggests that SE ideas became more robust over the years, as social entrepreneurship became more widespread, more accepted in circles concerned with sustainability and social problems, and probably also better funded. It also appears that social entrepreneurial ideas have a higher survival rate than other ideas.

\begin{tabular}{|c|c|c|c|c|c|}
\hline Year & $\begin{array}{c}\text { Total number of } \\
\text { ideas }\end{array}$ & $\begin{array}{c}\text { Ideas still active in 2015 } \\
(\% \text { of total })\end{array}$ & $\begin{array}{c}\text { Social entrepreneurial } \\
\text { (SE) ideas }\end{array}$ & $\begin{array}{c}\text { SE ideas still active in 2015 } \\
\text { (\% of SE ideas) }\end{array}$ & $\begin{array}{c}\text { SE ideas still active in 2021 } \\
(\% \text { of SE ideas) }\end{array}$ \\
\hline 2008 & 33 & $5(15 \%)$ & 8 & $3(38 \%)$ & $12(26 \%)$ \\
\hline 2009 & 276 & $60(21 \%)$ & 47 & $24(51 \%)$ & $10(22 \%)$ \\
\hline 2010 & 225 & $81(36 \%)$ & 57 & $41(72 \%)$ & $15(32 \%)$ \\
\hline 2011 & 218 & $114(52 \%)$ & 32 & $64(37 \%)$ \\
\hline 2012 & 152 & $233(77 \%)$ & 81 & $68(89 \%)$ & $10(31 \%)$ \\
\hline 2013 & 304 & $224(80 \%)$ & 76 & $229(66 \%)$ & $36(44 \%)$ \\
\hline 2014 & 279 & $812(55 \%)$ & 347 & $35(46 \%)$ \\
\hline Totals & 1487 & & & $129(37 \%)$ \\
\hline
\end{tabular}

Table 4: active and not active project-ideas

\subsection{Developing a product or service}

All social entrepreneurial project ideas aim to offer a solution to a societal problem, by delivering a product or service to those in need, or by producing products or delivering services to people willing to pay for it, while others benefit from it. Examples are lifestyle products made of plastic waste and produced in a social workplace, a vegan 'hamburger' made of seaweed that offers an alternative for meat, or a carsharing platform aiming to reduce the number of cars parked in the streets of big cities. Of all 347 project ideas, $64 \%$ had an idea to develop a product, $26 \%$ was aiming for a service, $9,5 \%$ proposed a combination of a product and a service, and 0,5\% could not be determined.

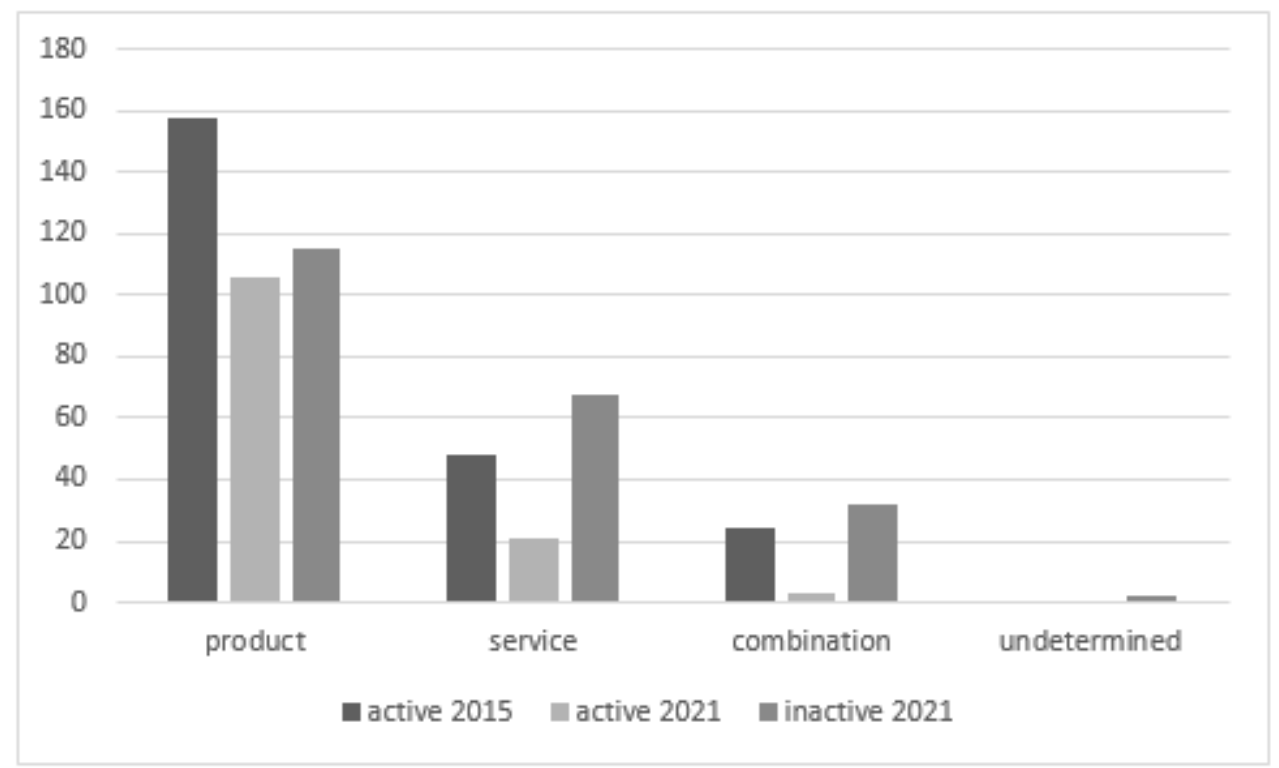

Figure 3: Choice to develop a product or service, divided over active and inactive project ideas 


\author{
E-ISSN: 2469-6501 \\ VOL: 7, ISSUE: 10 \\ October/202 1 \\ DOI: http://dx.doi.org/10.33642/ijbass.v7n10p4 \\ https://creativecommons.org/licenses/by/4.0/
}

Figure 3 shows active and inactive project ideas in 2015 and 2021 in combination with the choice for developing a product or service. The share of surviving project ideas that aim to develop a product (48\% in 2021) is much higher than the share of surviving service ideas (24\% in 2021). This finding is remarkable because the development, production, and distribution of physical products usually require bigger investments and bigger organizations than needed for a service.

\subsection{Market focus}

The 347 SE project ideas in the database offer sustainable alternatives for what is already there or develop something new to prove that sustainable products or services can be just as good, or better. Almost $71 \%$ of the project ideas focus on influencing consumers. The idea is to inspire consumers to make the right choice for a sustainable product. $22 \%$ of the ideas try to influence the behavior of companies and $7 \%$ are focused on both. The social entrepreneurial projects mainly $(72 \%)$ aim to execute their project idea in the Netherlands. The focus on foreign countries is $13 \%$ and on both the Netherlands and abroad is $15 \%$. If we compare the active project ideas with the inactive project ideas, we do not see any differences in these dimensions.

\subsection{Choice of theme}

Just as in the total collection of ideas, most initiators $(66 \%)$ of social-entrepreneurial project ideas had a 'planet' oriented project-idea that involved sustainable energy, environmental issues, or nature. The shares of social entrepreneurial initiators with 'people' oriented project ideas (i.e. the three other themes) are much smaller. This makes sense, as starting up a social enterprise that focuses on improving children's rights and education (1\%) is more difficult than for example selling solar panels. For social cohesion and safety (14\%), this is also the case, but selling fair trade clothing or food (23\%) is easier again and this is reflected in the number of project ideas in this theme. There is again no noticeable difference between the active and inactive project ideas.

\subsection{Outcomes of the first analysis of the entrepreneurial ideas}

Before we move further to an in-depth analysis of the description of the project ideas, we summarize what we have found so far. The project-ideas that we classified as social entrepreneurial tended to be:

- project-ideas that focused on influencing consumers by offering alternative products and services;

- project-ideas that had a national geographical focus;

- project-ideas that focused on planet-related issues, i.e. the theme 'sustainable energy, environment and climate'.

We did not find major differences between the active and the inactive project ideas except about the product versus service focus. Projects that focused on the development of a product had a significantly higher survival rate than projects focusing on the development of a service.
8. In-depth analysis of the social entrepreneurial project ideas

In search of other early signals of survival, we carried out an in-depth analysis of the description of the project ideas provided by the initiators. These descriptions give mainly information about social goals, but also contain some limited or hidden information on how business-wise or financially aware the initiators are.

\subsection{Method and discourse analysis}

We used the Nvivio software program for so-called discourse analysis. A discourse can be defined as "a specific ensemble of ideas, concepts, and categorizations that are produced reproduced and transformed in a particular set of practices and through which meaning is given to physical and social realities" (Hajer 1995, p.44). The description of project ideas by potential social entrepreneurs is a kind of discourse. The project description reveals what the initiators have at the top of their minds and the language they use describes their reality, ideas, and concepts. This discourse is used by the potential social entrepreneurs to mobilize resources for the execution of their project ideas and can be used by a potential supporter to get insights into their intentions, motivation, and aims. We used Nvivio to analyze the language used by the project initiators. Nvivio has also been used in other fields of research to analyze large amounts of written data (Santos et al. 2019; Lessa et al. 2017; Bridgstock et al. 2010; Surangi 2018).

The outcome of the analysis of the project ideas was a word count with the 1000 most used words with a length of at least five characters (in Dutch; in the following, we will use English translations of the words used). The underlying hypothesis was that surviving ideas would differ in their vocabulary from ideas that were no longer pursued. It should be noted that identical words often have different meanings when used in different contexts. Therefore, we did not calculate the statistical significance levels of the differences found, because it would suggest a measure of exactness that the data do not allow for. Instead, we limited ourselves to the differences that were around 10 percentage points or higher, which are so big that they would attract attention from even a casual observer. Moreover, we only looked at words that had been used at least 10 times.

\subsection{General results from the word count}

The highest-ranking words were, not surprisingly, related to sustainability. Many of the initiators use sustainability-related words to mobilize supporters for their ideas. Sustainability and sustainable were used 436 times; other related words like energy (153 times), environment (89 times), water (79 times), and nature (45 times) were also used frequently. Words that describe target groups for social change were also used many times, for example, people (321 times), women (101 times), and children (132 times). The term product is mentioned 279 times, which is also not surprising considering that many social entrepreneurial project-ideas are focusing on the development of a product. And the word 


\author{
E-ISSN: 2469-6501 \\ VOL: 7, ISSUE: 10 \\ October/202 1 \\ DOI: http://dx.doi.org/10.33642/ijbass.v7n10p4

clothing (122 times) is a frequently used word, which can be related to the fair trade, fashion, and food theme. The word fair is used 95 times. The Netherlands is used 125 times and also the term local (121 times) is high in the ranking. 'Soft' terms like together (119 times), the world (108 times), and living (108 times) are frequently used, or terms considering the social needs of people, like give (97 times), and need (96 times). Business terms were used less frequently than these more goalrelated terms.

\subsection{Business orientation}

In the list of words, we looked for business terms and words that indicated that the initiators were thinking about the mobilization of resources for their project ideas. We grouped these words into three categories, related to:

1. Organizational form

2. Customer orientation

3. The mobilization of financial means

In the following sections, we take a closer look at these three groups of words and relate them to the survival (active/not-active) of the idea in question. The underlying data can be found in the Appendices, which are available from the authors.

\section{Organizational form}

Only one of the 347 initiators used the expression 'social enterprise'. One can safely conclude that the term 'social enterprise' was new in the Netherlands in the period 2008-2014. Some initiators did have the idea that making money and creating social value could go hand in hand but used related words like company, enterprise, and the word entrepreneur. However, most initiators focused on describing their idea for social change about the product or service they wanted to develop. They were reaching out to the community VDWVM and its members. The organizational form they would need was not at the top of their mind at that time. Interestingly, however, the words company and/or business were used in $29 \%$ of the ideas that did not survive in 2015 but only in $18 \%$ of the ideas that did.

Words related to the production process, like recycling, raw materials, suppliers, and factory were also used relatively frequently. It appears that in this phase a potential start-up social entrepreneur is more concerned with the production process than with the future organizational form of his activity. The words 'chain' and 'resources' were used far more frequently by the survivors, while the word '(web)shop' was used more frequently by the initiators who were no longer active. This suggests that an early orientation on distribution mode and especially on physical shops is not necessarily a good signal for long-run survival, while an orientation on suppliers and needed resources may be helpful.

\section{Customer orientation}

There was a big difference in 2015 between the active and not active ideas, about the use of the words consumers and design, which were used more frequently in the still active projects. This suggests that these initiators were more inclined to think of their future customers as consumers who are not just interested in the good purpose, but also good design. However, the shares of surviving projects in 2021 using these words are far lower than the shares of the projects surviving in 2015. This means that the rate of survival was higher for the initiators who did not mention design. The active project ideas were also somewhat more inclined to mention terms like marketing and brand. However, only about $10 \%$ of the ideas that still survived in 2021 had used these terms.

\section{Mobilizing money}

Words like investments, investors, starting capital, and loans were rarely used. For a potential social entrepreneur, money is only one of many resources necessary to accomplish his goal. In the early stages, the initiator is not thinking about loans, equity, or other financial constructions. However, the initiators still active in 2015 mentioned (potential) demand and impact more frequently than the not-active initiators, while the latter used the term profit far more frequently $(8 \%$ versus $30 \%$ ). Also in 2021, the share of surviving projects that mentioned profit remains stable at less than $8 \%$. This suggests that at this early stage a clear focus on impact and customers is more important for survival than an orientation on profit.

We can conclude that there are some slight but noticeable differences between the surviving and the not surviving project ideas. The initiators of the still-active project ideas appear to be more concerned about the impact they make on society, the fair price they can ask for their product or service, and the way they can contribute to the needs of consumers. They pay attention to the market, the consumers involved, the impact they want to make, and the processes of production and development. The discontinued project ideas were more concerned with profit, costs, and investments. This leads to the somewhat paradoxical result that potential social entrepreneurs have a better chance of surviving if they are not too much concerned with the financial aspects of their proposal in the early stages of their project. Maybe, the surviving entrepreneurs were more inclined to accept financial advice, precisely because they did not have strong ideas of their own in this area.

\section{Conclusions}

Today, it is an accepted idea that you can change society with a mission-driven company, a social enterprise. Obviously, not every social enterprise will be successful. For impact investors, start-up social enterprises can be an interesting investment possibility, but it is a challenge to find a (potential) social enterprise with a business model that fits their investment criteria.

For impact investors who are scouting for investment opportunities, it might be good advice to search for potential social enterprises in an early stage of development that, contrary to what might be expected, are not much concerned with the basics of business but mainly focused on the social impact they want to achieve. This group of entrepreneurs will be open for cooperation and advice, as long as it allows them 


\author{
E-ISSN: 2469-6501 \\ VOL: 7, ISSUE: 10 \\ October/2021 \\ DOI: http://dx.doi.org/10.33642/ijbass.v7n10p4 \\ (c) () \\ https://creativecommons.org/licenses/by/4.0/
}

to achieve their social goals. Together, impact investor and into a business and help it grow into a successful social entrepreneur, they can develop the financial side of the idea enterprise.

\title{
References
}

Acs, Z.J., M.C. Boardman and C.L. McNeely. 2013. "The social value of productive entrepreneurship". Small Business Economics 40 (3): 785 - 796.

Agrawal, Anirudh; Hockerts, Kai (2021) Impact Investing. Review and Research Agenda, Journal of Small Business \& Entrepreneurship Volume 33, 2021 - Issue 2, 153-181

Arena, M., I. Bengo , M. Calderini , and V. Chiodo, 2018. "Unlocking Finance for Social Tech Start-ups: Is There a New Opportunity Space?" Technological Forecasting and Social Change 127: 154-165

Austin, J., H. Stevenson and J. Wei-Skillern. 2006. "Social and commercial entrepreneurship: Same, Difference or both?" Entrepreneurship Theory and Practice 30 (1): 1-22.

Bazeley, P. and L. Richards. 2000. The NVivo qualitative project book. London: Sage.

Bugg-Levine, A., B. Kogut and N. Kulatilaka. 2012. A new approach to funding social enterprises. Harvard Business Review 90 (1/2): 118-123.

Bridgstock, R., F. Lettice, M.F. Oezbilgin and A. Tatli. 2010. Diversity management for innovation in social enterprises in the UK. Entrepreneurship and regional development 22 (6): 557-574.

CNN-http://money.cnn.com/2017/06/27/investing/impact-investing-growth/index.html

Cohen, R. and W.A. Sahlman. 2013. Social Impact Investing Will Be the New Venture Capital. Harvard Business Review. https://hbr.org/2013/01/social-impact-investing-will-b/

Dacin, P.A., M.T. Dacin and M. Matear. 2010. Social entrepreneurship: why we don't need a new theory and how we move forward from here. Academy of Management Perspectives 24 (3): 37-57

Dees, J.G. 1998. The Meaning of social entrepreneurship. Revised May 2001, original draft, available at http://www.fuqua.duke.edu/centers/case/ documents/Dees_SEdef.pdf.

Dees J.G., Emerson J., and Economy, P. eds. 2002. Strategic tools for social entrepreneurs: Enhancing the performance of your enterprising nonprofit. New York: John Wiley \& Sons, Inc.

Dees, J.G. and B. Battle Anderson. 2006. Framing a theory on social entrepreneurship, Building on two schools of practice and thought. ARNOVA Occasional Paper Series, 1 (3), edited by Rachel Mosher-Williams. Aspen institute.

Financial Times - https://www.ft.com/content/d8b6d9fa-4eb8-11e8-ac41-759eee1efb74

Geobey, S., F.R. Westley and O. Weber. 2012. Enabling Social Innovation through Developmental Social Finance. Journal of Social Entrepreneurship. 3 (2): 151-165

Groot, A. and B. Dankbaar. 2014. Does social innovation require social entrepreneurship? Technology Innovation Management Review. December: 17-26.

Hajer, M. 1995. The politics of environmental discourse: ecological modernization and the policy process. Oxford: Oxford University Press

Hoogendoorn, B., H.P.G. Pennings and R. Thurik. 2010. What Do We Know About Social Entrepreneurship: An Analysis of Empirical Research. Erasmus Research Institute of Management (ERIM) Report Series Research in Management ERS2009-044-ORG. Erasmus University Rotterdam.

Kramer, M. 2005. Measuring Innovation: Evaluation in the Field of Social Entrepreneurship. Boston, Mass.: Foundation Strategy Group.

Leadbeater, C. 1999, Living on Thin Air, London: Penguin Books

Lessa, B.D., A.C.A.A. de Souza, R.C. Ferreira and I.C. Aguiar. 2017. Innovating for social demands - a double case study in effective social enterprises from the Brazilian Semiarid. Gestao e desenvolvimento, 14 (2): 4-18.

Light, P.C. 2008. The Search for Social Entrepreneurship. Washington D.C.: Brookings Institution Press.

Lumpkin, G.T., T.W. Moss, D.M. Gras. S. Kato and A.S. Amezcua. 2013. Entrepreneurial processes in social contexts: how are they different, if at all? Journal of Small Business Economics 40 (3): 761-783.

Macke, J., J.A. Rubim Sarate, J. Domeneghini and K. Aparecida da Silva. 2018. Where do we go from now? Research framework for social Entrepreneurship. Journal of Cleaner Production 183: 677-685. 
Mair, J. and I. Marti. 2006. Social entrepreneurship research: a source of explanation, prediction, and delight. Journal of World Business 41 (1): 36-44.

Moore, M-L., F.R. Westley and A. Nicholls. 2012, The Social Finance and Social Innovation Nexus, Journal of Social Entrepreneurship 3 (2): 115-132

Mort, G. S., J. Weerawardena and K. Carnegie. 2003. Social entrepreneurship: Towards conceptualisation. International Journal of Entrepreneurial Behaviour \& Research 8 (1): 76-88.

Nicholls, A. and A.H. Cho. 2006. Social Entrepreneurship: The Structuration of a Field. In Social Entrepreneurship. New Models of Sustainable Social Change, edited by A. Nicholls, 99-118. Oxford: Oxford University Press

Ormiston, J., K. Charlton, M.S. Donald and R.G. Seymour. 2015. Overcoming the Challenges of Impact Investing: Insights from Leading Investors, Journal of Social Entrepreneurship 6 (3): 352-378

Perrini, F. and C. Vurro. 2006. Social entrepreneurship: innovation and social change across theory and practice. In Social Entrepreneurship, edited by J. Mair, J. Robinson and K. Hockert, 57-85. New York: Palgrave Macmillan.

Roundy P., H. Holzhauer and Y. Dai. 2017. Finance or philanthropy? Exploring the motivations and criteria of impact investors, Social Responsibility Journal 13 (3): 491-512.

Santos, F.M. 2012. A positive theory on social entrepreneurship. Journal of Business Ethics 111 (3): 335-351.

Santos, G., C.S. Marques and V. Ratten. 2019. Entrepreneurial women's networks: the case of D'Uva - Portugal wine girls. International journal of entrepreneurial behaviour \& research 25 (2): 298 - 322.

Scott Marshall, R. 2011. Conceptualizing the International For-Profit Social Entrepreneur. Journal of Business Ethics 98 (2): 183-198

Short, J.C., T.W. Moss and G.T. Lumpkin. 2009. Research in social entrepreneurship: Past contributions and future opportunities. Strategic Entrepreneurship Journal 3 (2): 161-194.

Seelos, C. and J. Mair. 2005. Social entrepreneurship: Creating new business models to serve the poor. Business Horizons 48, $241-246$

Surangi, H. 2018. What influences the networking behaviours of female entrepreneurs?: A case for the small business tourism sector in Sri Lanka. International Journal of Gender and Entrepreneurship 10 (2): 116-133.

Weerawardena, J. and G.S. Mort. 2006. Investigating social entrepreneurship: A multidimensional model. Journal of World Business 41 (1): 21-35.

Wilson, F. and J.E. Post. 2013. Business models for people, planet (\& profits): exploring the phenomena of social business, a market-based approach to social value creation. Journal of Small Business Economics 40 (3): 715 - 737. 